Karolina Drozdowska

Uniwersytet Gdański

\title{
Fra Ornitofilene til Fugleelskerne. En analyse av tekstutvikling (Notater fra et forskningsbesøk i Holstebro)
}

\author{
From Ornitofilene to Fugleelskerne. \\ An analysis of text development (Notes from a research visit to Holstebro)
}

The aim of this text is to conduct a comparative analysis of two versions of the same text: The Bird Lovers by Jens Bjørneboe. During my stay at Odin Teatret in August and September 2016, I came across a version of the play's manuscript from 1964, which I have compared to the play's final version printed two years later. Jens Bjørneboe's collaboration with Eugenio Barba and the history of Ornitofilene, the first play staged by the theatre, play a very significant role in the article. I try to place the changes made to the text in a historical context, showing how a Grotowski-inspired play can influence a Brecht-inspired play and also how and why the text developed over time.

Key words: The Bird Lovers, Jens Bjørneboe, Eugenio Barba, Odin Teatret, epic theatre

Nøkkelord: Fugleelskerne, Jens Bjørneboe, Eugenio Barba, Odin Teatret, episk teater

\section{Innledning}

Målet med denne teksten er å gjennomføre en komparativ analyse av to tekster: Jens Bjørneboes skuespill Fugleelskerne fra 1966 (i denne teksten bruker jeg versjonen utgitt av Pax i boken Samlede skuespill fra 2005) og første versjon av samme skuespill fra desember 1964, som Bjørneboe ga til sin venn, den italienske teatermannen Eugenio Barba. Jeg skal forsøke å se på hovedforskjeller mellom de to versjonene og samtidig følge utviklingsprosessen av skuespillets tekst, med særlig fokus på hvordan fremføringen ved Odin Teatret (ledet av Barba) i 1965 bidro til noen vesentlige endringer i dramaets opprinnelige versjon.

Før jeg kommer til selve analysen, blir jeg nødt til å forklare hvor ideen til denne artikkelen kom fra, og hvordan jeg klarte å få tak i skuespillets første ver- 
sjon: Jeg har nemlig arbeidet med Bjørneboes forfatterskap i mange år, og i doktoravhandlingen min fra 2014 valgte jeg å fokusere på de to stykkene som Janet Garton (1985: 69) kaller for «episke» eller «brechtianske»: Fugleelskerne samt Til lykke med dagen fra 1965 (Bjørneboe 2005b). I mitt arbeid med disse to dramaene fant jeg ut at det finnes et "polsk motiv» som er klart forbundet med det førstnevnte skuespillet. Jeg bestemte meg for å følge denne tråden og, etter at jeg hadde fullført doktoravhandlingen, satte jeg i gang med et nytt prosjekt som hadde som mål å nærmere undersøke forbindelsen mellom det polske og det norske teatermiljøet på 1960-tallet. Som en del av forskningsarbeidet knyttet til dette prosjektet, reiste jeg i perioden 29. august til 7. september 2016 til den danske byen Holstebro, der Barbas Odin Teatret holder til. Der fikk jeg både gå gjennom teatrets arkiver (OTA) og snakke med Barba og norske Else Marie Laukvik, (henholdsvis 6. og 1. september 2016) en av de fire skuespillerne som var med på å forberede fremføringen av Ornitofilene i 1965. Det var også hun som ga meg den aller første versjonen av skuespillet. For å kunne forklare hvorfor dette er så viktig, er jeg nødt til å stoppe litt her og komme med en historisk innledning.

\section{Bjørneboe, Barba og Odin Teatret}

Italieneren Barba ble født i Brindisi i 1936. Faren hans var soldat, men Eugenio drømte om en karriere som kunstner. I 1954 dro han til Norge der han først jobbet som fabrikkarbeider i noen år og deretter begynte å studere ved Universitetet i Oslo. Barba traff Bjørneboe på slutten av 1950-tallet. Ut fra det vi kan lese hos Kvamme (2004: 59-60), ringte han bare den berømte nordmannen og ba om et møte. Siden Bjørneboe likte å omgås utenlandske intellektuelle, sa han fort ja. Dette var begynnelsen på et langvarig vennskap mellom de to - et vennskap som også fikk betydning for norsk teaterhistorie.

I 1961 dro Barba - etter at han hadde latt seg begeistre av Andrzej Wajdas film Aske og diamant - til Polen der han først begynte å studere ved Universitetet i Warszawa og deretter ved Statens Teaterhøgskole (PWST) i hovedstaden. Det samme året reiste han - sammen med sin norske venn Dag Halvorsen - til Opole, der han så en fremføring av Dziady (Forfedre) på 13 Raders-teatret, ledet av Jerzy Grotowski. Nyttårsaften 1961 tilbrakte Barba i Zakopane, der han ble kjent med den polske regissøren og teatermannen. Da han fikk tilbud om å flytte til Opole og bli Grotowskis assistent, takket han ja med det samme (Turner 2004: 4-6).

Helt fra Barba flyttet til Opole, jobbet han iherdig med formidling av norsk kultur i Polen, og polsk kultur i Norge. I den forbindelse holdt han tett kontakt med Bjørneboe - de utvekslet mange brev gjennom Barbas «polske år». Disse 
brevene er tilgjengelige i arkivene til Odin Teatret ${ }^{1}$, de aller fleste av dem har også blitt trykt i Elsa Kvammes bok Kjore Jens, kjoere Eugenio fra 2004. Jeg skal ikke gå nærmere inn på verken teaterteoriene bak Grotowskis virksomhet ved 13 Raders-teatret eller polsk-norsk kulturutveksling her (siden disse spørsmålene er såpass omfattende at de fortjener hver sin egen tekst). I stedet vil jeg nevne at de to vennene begynte å utveksle ideer om stykket de i denne perioden kalte for Ornitofilene/Fuglevennene allerede i januar 1963 (etter at Barba hadde tilbragt julen i Norge sammen med Bjørneboe og hans familie). Store planer ble lagt i forbindelse med stykket: I brevet fra 29. januar 1963 kan vi lese at Bjørneboe ønsket å starte sitt eget teater der skuespillet skulle bli vist, med Barba som regissør. Senere (16. februar) nevner den norske forfatteren at dramaet kunne filmatiseres av Wajda, i Italia. I et annet brev, datert 18. mars samme år, opplyser Bjørneboe om at han hadde sendt en uferdig versjon av manuset til Wajda og at teksten, etter hans egen mening, var «språklig forferdelig». Vi kan dermed se at vennene på en eller annen måte jobbet med skuespillets tekst sammen, antakelig helt fra desember 1962.

I 1964 var Barba nødt til å komme tilbake til Norge etter å ha blitt «persona non grata» i Polen ${ }^{2}$. Han bestemte seg for å starte sitt eget teater, og den 1. oktober 1964 ble Odin Teatret åpnet i Oslo. Skuespillerne ble rekruttert blant unge mennesker som ikke kom inn på Statens Teaterhøgskole, og Barbas metode kunne beskrives som sterkt preget av Grotowski. Etter en stund var det bare fem skuespillere igjen ${ }^{3}$ : tre kvinner (Anne Trine Grimnes, Else Marie Laukvik og Torill Øyen) og to menn (Tor Sannum og Torgeir Wethal). Disse var med på å forberede teatrets første forestilling ${ }^{4}$.

Laukvik skriver (i en maskinskrevet tekst tilgjengelig i arkivene til Odin Teatret):

${ }^{1}$ OTA (Odin Teatret Archives) - Documents, Fonds Eugenio Barba, Series Letters, BarbaLetters, b. 1.

${ }^{2}$ Det polske hemmelige politiet hadde mistanker om at Barba, som reiste mye til utlandet, kunne drive spionasje. Alle dokumentene forbundet med det polske hemmelige politiets overvåkning over Barba kan man både finne i arkivene til Polsk institutt for nasjonal hukommelse (IPN) og i arkivene til Odin Teatret: OTA (Odin Teatret Archives) - Documents, Fonds Eugenio Barba, Series Miscellaneous, Barba-Miscellaneous, b. 7. Det har også blitt skrevet en meget god tekst om detaljer rundt denne saken av Agnieszka Wójtowicz (2014).

${ }^{3}$ Dette skjedde fordi flere av de unge skuespillerne som opprinnelig ble rekruttert, slet med hard fysisk trening som var en del av Barbas metode på den tiden, og bestemte seg for å forlate teateret.

${ }^{4}$ Odin Teatret flyttet fra Oslo til Holstebro i Danmark våren 1966 - de danske myndighetene kunne tilby Barba og hans team bedre økonomiske vilkår og dessuten egne øvingslokaler - på en gammel bondegård utenfor byen. Det er der teatret og arkivene har befunnet seg til dags dato, og det var dit jeg reiste i august/september 2016.

${ }^{5}$ Maskinskrevet tekst i OTA (Odin Teatret Archives) - Documents, Fonds Odin Teatret, Series Performances, Sub-Series Perf-B, Perf-B, b. 1., s. II. 
Ved juletider fikk vi Bjørneboes manuskript «Fugleelskerne», og det ble anledning til å snuse begjærlig på de første utdelte replikker. I manuskriptet var det 13 roller hvorav kun én var kvinnelig. Barba strøk alle egennavn og stedsnavn og ommøblerte og sløyfet en del replikker, slik at det ble tekst til fire roller som ikke var avhengige av spesielle sceneanvisninger.

Bjørneboe ga dermed sin italienske venn en «uferdig» versjon av skuespillet, sammen med tillatelse til å kutte, endre og bearbeide så mye han følte behov for. Hans eneste ønske var at Barba skulle «bevare hans ånd» (Rem 2010: 190).

\section{Forvirring rundt forskjellige versjoner av skuespillet}

Sluttresultatet av dette arbeidet er tilgjengelig for offentligheten på nettsidene til OTA. Her kan man finne både dokumentet «Original text of the performance, 1964» (Odin Teatret 1964 [1965?]) samt et dokument ved navn «Text of the performance revised by Else Marie Laukvik, 2008» (Odin Teatret 2008). Mens det er ganske åpenbart at det sistnevnte dokumentet er skuespillets endelige tekst, rekonstruert av skuespilleren, er det tvilsomt om det maskinskrevne dokumentet «Original text...» virkelig er fra 1964. Else Marie Laukvik, i vår samtale den 1. september 2016, fortalte at da Barba fikk manuskriptet fra Bjørneboe, ble det hennes oppgave å taste hele teksten inn på en skrivemaskin. Hun brukte lang tid på denne jobben, og derfor ble hun veldig skuffet, siden det i etterkant viste seg at hun ikke fikk en eneste replikk. Det var først da Torill Øyen forlot teatret sommeren $1965^{6}$ at Laukvik fikk sine replikker - hun overtok «100\% av Øyens rolle», som hun sa i samtalen med meg. I dokumentet «Original text...» ser man dermed at replikkene er fordelt mellom fire personer, alle markert med initialer: AT (antakelig Anne Trine [Grimnes]), TG (antakelig Torgeir [Wethal]), BJ (antakelig Tor Sannum det er uklart for meg hvor initialene kommer fra) samt EM (antakelig Else Marie [Laukvik]). Denne fordelingen stemmer forresten overens med fordelingen man ser i det ovennevnte dokumentet fra 2008. Det er derfor mer sannsynlig at dokumentet ved navn «Original text...»er fra 1965, ikke 1964.

I tillegg til de to dokumentene nevnt ovenfor, kan man finne diverse scenarioversjoner i OTA, nærmere sagt i dokumentene overlevert til arkivet av Torgeir Wethal ${ }^{7}$. Odin Teatrets scenario hadde tydeligvis flere versjoner. Som Laukvik uttrykker det: «I lang tid hadde forestillingen hatt en kaotisk, tåkete og springende

\footnotetext{
${ }^{6}$ Laukvik skriver i notatene: «Den 19. august møttes vi på nytt, men nå med én mindre. Torill hadde sviktet oss til fordel for det konvensjonelle og aksepterte teater. Ca. en måned senere begynte hun på Statens Teaterhøgskole» (Maskinskrevet tekst i OTA (Odin Teatret Archives) - Documents, Fonds Odin Teatret, Series Performances, Sub-Series Perf-B, Perf-B, b. 1., s. III). ${ }^{7}$ OTA (Odin Teatret Archives) - Documents, Fonds Wethal, Series Wethal, Wethal, b. 39.
} 
karakter. Men litt etter litt fikk den sin egen spesielle form; kropp og bevegelser ble samordnet og ansiktstrekkene ble langsomt avdekket ${ }^{8}$. Blant disse dokumentene fant jeg 23 sider av et maskinskrevet scenario som antakelig var den aller første versjonen, altså versjonen Barba fikk fra Bjørneboe ved juletiden 1964. Her sto det navn (f.eks. «MARCO», «CAVALI», «PICC.») i stedet for initialer. Disse navnene ble imidlertid strøket med sort tusj/blå kulepenn og initialer/navn ble satt ved siden av: «AT» (antakelig Anne Trine [Grimnes]), «Torill» (antakelig Øyen), «Tor» (antakelig Sannum), «TW» (antakelig Torgeir Wethal). I tillegg til navnene ble noen deler av replikker strøket, og noen ord/deler av setninger føyd til med tusj eller penn (de fleste er uleselige for meg). I tillegg virker det som om endringene innført med svart tusj er nyere enn endringene innført med penn - navnet «Torill», som er skrevet med blå penn, ble for eksempel strøket på en av sidene og erstattet med initialene «EM» (antakelig Else Marie [Laukvik]), som er skrevet med svart tusj. Her er det dermed sannsynligvis snakk om endringer innført i den opprinnelige versjonen av stykket Barba mottok fra Bjørneboe, i forskjellige perioder mellom 1964 og 1965. Men ett spørsmål gjensto: Hvor var den originale teksten som kom fra den norske forfatteren i 1964 (i sin uendrede versjon)? Jeg kunne ikke finne det i OTA, og OTAs meget kompetente og hjelpsomme ansatte bekreftet at de ikke hadde denne ressursen hos seg. Derfor var dette et av spørsmålene jeg stilte Laukvik i samtalen vår den 1. september 2016. Laukvik virket overrasket da hun fikk høre at scenarioet ikke fantes i arkivene, og påsto at det lå hjemme hos henne et sted. Allerede neste dag kom hun med en bunke tynne, nesten gjennomsiktige ark som - til min og de ansatte ved OTAs store overraskelse - viste seg å være Bjørneboes originale tekst fra 1964, tastet inn på maskin av Laukvik. Dermed fikk jeg tak i denne verdifulle ressursen som fra og med september 2016 også ble inkludert i OTAS dokumenter?.

Derfor, når jeg senere i denne teksten viser til «den originale/første versjonen av Fugleelskerne», mener jeg nettopp dette dokumentet.

\section{Barbas Ornitofilene og Bjørneboes Fugleelskerne}

Odin Teatrets Ornitofilene fikk sin premiere den 12. oktober 1965 (Odin Teatret 2008). Når man ser på bilder og audiovisuelle opptak fra forestillingene (Odin Teatret 1965), kan man utvilsomt konkludere med at skuespillet bærer tydelig preg av Grotowskis teater. Stykket ble spilt 51 ganger - 9 ganger i Oslo og 42 ganger i forskjel-

\footnotetext{
${ }^{8}$ Maskinskrevet tekst i OTA (Odin Teatret Archives) - Documents, Fonds Odin Teatret, Series Performances, Sub-Series Perf-B, Perf-B, b. 1., s. II.

${ }^{9}$ Som del av OTA (Odin Teatret Archives) - Documents, Fonds Odin Teatret, Series Performances, Sub-Series Perf-B, Perf-B, b. 1.
} 
lige byer i Norge, Sverige, Danmark og Finland ${ }^{10}$. Det fikk særlig entusiastisk kritikk i Danmark (i forhold til ganske blandet mottak i Norge) ${ }^{11}$, noe som sikkert også var tatt med i betraktningen når det ble bestemt at teatret skulle flyttes til Holstebro.

I mellomtiden arbeidet Bjørneboe med «sin» versjon av skuespillet. Det kom ut (under tittelen Fugleelskerne) våren 1966 i Gyldendals grønne serie, og fikk sin premiere den 11. november samme år, på Nationaltheatret, med Henki Kolstad og Wenche Foss i hovedrollene. I dokumentarfilmen Jens Bjørneboe - Diktere og masochister fra $2004^{12} \mathrm{kan}$ man se et kort utsnitt av forestillingen. Det er ingen tvil om at Bjørneboes versjon var veldig, veldig forskjellig fra den man kunne se hos Barba - ikke bare på grunn av en annerledes/bearbeidet tekst, men også selve stilen: Mens Barbas forestilling var sterkt inspirert av Grotowski, bærer Bjørneboes Fugleelskerne tydelig preg av Bertolt Brechts teaterteori ${ }^{13}$. Også denne versjonen av «Fuglevennene» ble mottatt med «blandede følelser» i Norge, og stykket spilte forresten en rolle i skandalen som opptok Oslos teaterverden i 1967: Skuespillet ble nemlig invitert til Teaterfestivalen i Venezia, men Nationaltheatret takket nei til invitasjonen. Dette vekket stor forargelse blant mange, særlig - forståelig nok hos Bjørneboe, som i en sarkastisk artikkel (Bjørneboe 2003a) tok et hensynsløst oppgjør med hele det norske teatermiljøet.

Det er dermed den trykte teksten fra 1966 (i 2005-utgaven) jeg kommer til å vise til når jeg skriver om Fugleelskernes endelige versjon.

\section{Fugleelskerne AD 1964 vs. Fugleelskerne AD 1966 - en analyse}

Først og fremst er det viktig å beskrive hva slags materiale jeg arbeider med når det gjelder originalteksten. Her er det snakk om et digitalisert (originaldokumentet som Else Marie Laukvik kom med, ble skannet av arkivmedarbeiderne), maskin-

${ }_{10} 19$ forestillinger i Norge, 16 i Danmark, 8 i Sverige og 8 i Finland. En liste over de forskjellige forestillingene kan man finne i: OTA (Odin Teatret Archives) - Documents, Fonds Odin Teatret, Series Activities, Activities, b. 1.

${ }^{11}$ Forestillingens presseomtaler (både norske, danske, svenske og finske) er bl.a. tilgjengelige i: OTA (Odin Teatret Archives) - Documents, Fonds Odin Teatret, Series Performances, SubSeries Perf-B, Perf-B, b. 1.

${ }^{12}$ Laget av programskaperen Jan Horne og prosjektlederen Vibeke Haug.

${ }^{13}$ Bjørneboes forhold til Brecht er et veldig sammensatt emne som jeg ikke skal utdype i denne teksten - jeg gir en detaljert beskrivelse av problemet i min doktoravhandling fra 2014. Det jeg imidlertid vil nevne her, er at Bjørneboe ønsket å bryte med tradisjonelt teater slik det på hans tid ble oppfattet i Norge. Den amerikanske forskeren Joe Martin skriver at han var «The second, after Nordahl Grieg, to 'cast off the Ibsenite leg-irons'» (Martin 1996: 5). Det skrives forholdsvis lite om norske teaterfolk mellom Ibsen og Fosse. Det var først Ivo de Figueiredo som rettet søkelyset mot dem (også Bjørneboe) i sin bok Ord/kjøtt. Norsk scenedramatikk 1890-2000, utgitt i 2014. 
skrevet scenario på til sammen 53 sider (der de første to sidene ikke er nummerert). Dette er et gammelt dokument, og slitasje på papiret gjorde at noen replikker ble ganske vanskelige å tyde - noe som ble enda verre under digitaliseringsprosessen. Det er imidlertid kun enkelte setninger som er delvis eller fullstendig uleselige i den skannede versjonen. Det som kanskje er mest påfallende, er at det virker som om originaldokumentet er sammensatt av to forskjellige versjoner: Scene 21 slutter på side 27 , mens scene 22 begynner på toppen av side 33 . Her har altså hele fem sider blitt «borte» uten at noen deler av teksten forsvant samtidig. Det er også to forskjellige detaljer som tyder på at dokumentet egentlig består av deler fra to forskjellige versjoner: På side 1-27 står sidenummeret øverst på arket, midt på siden. På side 33-56 derimot, er sidenummeret plassert øverst til venstre. Samtidig er teksten på side 33-56 mye mer leselig (ingen uleselige elementer i det hele tatt) enn den som står på side 1-27, noe som kan tyde på at en annen type papir ble brukt på disse sidene. Ulik nummerering og papirkvalitet kan muligens tjene som bevis på at stykkets originalversjon egentlig består av deler fra to dokumenter. Samtidig vet vi at Laukvik tastet inn teksten i flere eksemplarer (noe hun også bekreftet i samtalen vår den 1.09.2016). Av dette kan man med stor sannsynlighet (dog uten $100 \%$ sikkerhet) konkludere at begge versjonene dokumentet består av, kommer fra samme tid, og at det bare er snakk om to eksemplarer av samme tekst.

Man kan også være ganske sikker på at, til tross for «manglende sider» (sidene 28-32 finner man ikke i dokumentet), har ingen elementer av selve teksten gått tapt - teksten øverst på side 33 begynner nøyaktig der scene 21 på side 27 slutter.

«FUGLEELSKERNE» lyder tittelen på den første, unummererte siden. Under dette står det: «Scenario av Jens Björneboe ${ }^{14} »$. Den neste siden (også uten nummer) inneholder en liste over personer i skuespillet, en beskrivelse av stedet handlingen finner sted (den italienske byen Torre Rosse) og mottoet samt opplysningen om at «pause kan legges inn mellom 23. og 24. scene». Denne siden er i hovedsak veldig lik tilsvarende side i Bjørneboes 1966-versjon (Bjørneboe 2005a: 89). Riktignok er det noen forskjeller på detaljnivå (f.eks. det at «En dommer» og «En oppasser» blir nevnt på listen fra 1964, mens i 1966-versjonen blir disse personene utelatt, siden det er henholdsvis Greifenklau og Johannes som inntar disse rollene). Den kanskje mest påfallende forskjellen er at Fugleelskernes leder, Huldreich von U. zu Greifenklau (ifølge 1966-versjonen), heter Dr. jur. Ehrenreich von Ziegenstein i 1964-originalen. I tillegg er Carusos navn ikke med på listen i 1964-dokumentet, selv om han selvfølgelig spiller en viktig rolle i selve stykket. Det er umulig å si om denne forseelsen kom fra forfatteren eller personen som tastet teksten inn. Ellers er alt stort sett det samme - mottoene er identiske, det samme kan sies om opplysningen om sceneskiftet mellom scene 23 og 24 .

$\overline{14}$ «Ö»-tegnet blir brukt i stedet for «ø» gjennom hele manuset. 
I begge skuespillene er det til sammen 29 scener. I 1966-versjonen ble en stor del av siste scene atskilt fra resten av teksten og fikk sin egen tittel: «Rettssaken» (Ibid.: 135). I den originale versjonen kan man riktignok ikke snakke om slike mellomtitler, men på et rent tekstuelt nivå blir scenene ganske like.

Det som kan være litt morsomt å nevne, er at skuespillets endelige versjon inneholder dedikasjonen «til Eugenio» helt i begynnelsen (som ikke er med i originalversjonen), og i tillegg en liten «hilsen» til Barba, vevd inn i teksten. I den ovennevnte scene 29 , når Caruso en gang til står foran sine gamle bødler, gjenkjenner Ziegenstein/Greifenklau ham og lurer på hvordan i all verden han klarte å overleve henrettelsen. I 1964-versjonen svarer Caruso: «Min stamfar var condottiere Atilla Gentile. Familien Gentile har gjennom 700 år vært berømt for sitt fremragende grokjøtt» (Bjørneboe 1964: 44). I versjonen fra 1966 svarer Caruso litt mer utfyllende, nemlig: «Siden min stamfar condottieren Atilla Gentiles dager har min familie vært berømt for sitt fremragende grokjøtt. Hans sønnesønn Eugenio Teodoro Barba skal sågar ha overlevet en halshugging» (Bjørneboe 2005a: 137). Bjørneboe ønsket sannsynligvis å «takke» sin italienske venn for samarbeidet rundt skuespillet, og bestemte seg derfor for å bake denne humoristiske referansen inn $\mathrm{i}$ «sin» versjon av stykket.

Det hadde seg nemlig slik, at den norske forfatteren - selv om han, som sagt, lot vennen sin gjøre det han ville med det opprinnelige manuskriptet - av og til fulgte med på prøvene til Odin Teatret (Rem 2010: 190), og hentet inspirasjon derfra. På denne måten ble en betydelig endring innført i den endelige 1966-versjonen.

I 1964-originalen er avslutningen på skuespillet ganske udramatisk: Riktignok blir Ziegenstein og Johannes dømt til døden selv etter Piccolinos lidenskapelige forsvarstale, men til slutt klarer fuglevennene å overbevise Cavalli, Fidele, Sandro, Marco og til og med Caruso, om at det ville være mye gunstigere å la de tyske økologene etablere et «ferieparadis» i Torre Rosse enn å henrette de tidligere nazistiske bødlene. Her er det økonomiske motiver som blir prioritert, og hele den italienske gruppen bestemmer seg for å «selge» idealene sine. Avslutningen blir altså veldig pessimistisk, men ganske udramatisk: Italienerne lar seg overbevise av fuglevennenes idé, én etter én, med Caruso som den mest «trofaste» på slutten. Riktignok kommer Sandro med noen spake protester, men kun fordi han selv er landarbeider og ikke kommer til å tjene noe på «ferieparadiset». De andre legger ikke særlig merke til ham. Det eneste Caruso lurer på, er om fugleelskerne kommer til å holde sitt løfte: «Er det ikke for sent allikevel? Kommer de ikke til å anmelde oss og til å legge ferieparadiset et annet sted etter dette?» (Bjørneboe 1964: 55). Ziegenstein forsikrer ham om at avtalen skal holdes: «Mine herrer, De har mitt æresord som offiser!» (Ibid.: 56). Dette er originalens siste replikk.

Barba bestemte seg for å vri litt på denne avslutningen - han endret scenarioet slik at faren (spilt av Wethal), som ikke var i stand til å leve med det at resten 
av «familien» (siden Barba kun hadde fire skuespillere måtte han «redusere» hele byen til en kjernefamilie) lot seg kjøpe av ornitofilene, skulle henge seg på slutten. Dette var en oppgave som viste seg å være ganske vanskelig rent teknisk, med tanke på hvordan scenerommet hos Barba ble organisert. Dette kan man se på filmen fra prøvene, som ligger på YouTube (Odin Teatret 1965). Laukvik beskriver scenerommet på følgende måte: «Arkitekturen besto av ca. 100 stoler, syv bord, to små bord som vi hadde snekret selv, og en stor kasse som ble dekket med sort stoff. Det hele var satt opp på en slik måte at de kunne gi mange assosiasjoner: møtelokale, rettssal eller kirke» ${ }^{15}$. Sluttscenen jeg beskriver, skulle altså bestå i at Wethal måtte klatre på et lite bord, deretter på den store kassen for så deretter å «henge seg» i en løkke som var montert i taket sammen med et gevær (en ganske komplisert konstruksjon). Den unge skuespilleren klarte ikke denne oppgaven. Med løkken rundt halsen gikk han ut av rollen og sa - som seg selv, ikke som «far»: «Jeg kan ikke, jeg tør ikke». Laukvik mente derimot at hun kunne klare denne scenen, og derfor ble slutten på skuespillet endret slik at det var datteren som hang seg, ikke faren, mens Wethals utbrudd «Jeg kan ikke, jeg tør ikke» ble inkorporert i skuespillet som farens replikk. Denne historien er gjenfortalt i bind to av Tore Rems store Bjørneboe-biografi fra 2009 og 2010 (Rem 2009; Rem 2010: 191), og da jeg spurte Laukvik om dette i samtalen vår den 1. september 2016, bekreftet hun smilende: «Ja, jeg syntes det gikk helt fint!». Det var dessuten da, forklarte Laukvik, at ordene «Ve fedre som svikter, for barn skal bøte for dem» (Odin Teatret 1964 [1965?]: upaginert, siste ark (9)) ble føyd til skuespillets tekst.

Bjørneboe må ha vært begeistret for denne endringen - kanskje landet han på at en slik reaksjon er veldig menneskelig. I alle fall bestemte han seg for å bruke replikken i den endelige versjonen av stykket. I sluttscenen av 1966-teksten lar italienerne seg kjøpe, akkurat som i 1964-originalen. Men Caruso står igjen. Han synes at siden kameratene hans solgte idealene, er det å ta sitt eget liv det eneste riktige (i den grad ligner han på Barbas far- og, senere, datterrolle). Han klatrer på stolen og knytter løkken rundt halsen. Alle ser på ham med forventning. En lang pause følger, også:

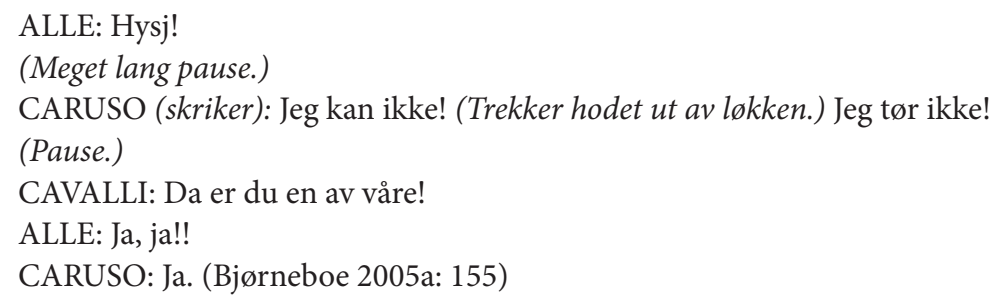

${ }^{15}$ Maskinskrevet tekst i OTA (Odin Teatret Archives) - Documents, Fonds Odin Teatret, Series Performances, Sub-Series Perf-B, Perf-B, b. 1., s. II. Jeg vil for øvrig nevne at det var Ole Daniel Bruun som stod for forestillingens scenografi. 
Deretter blir det erklært at «Gruppe 43 er en bloc overgått til fugleelskerne». Caruso kneler foran Greifenklau og Johannes og ber dem om tilgivelse. De omfavner og kysser ham. "Okkupasjonsmaktens gamle emblem senkes ned og fyller bakgrunnen». «Motivet fra Den 9. symfoni spilles: 'Seid umschlungen, Millionen!'». Så er det slutt (Ibid.). Ingen henger seg.

Her er det anvendt mangfoldige midler for å understreke det som denne avslutningen symboliserer: menneskets endelige og uvilkårlige undergang. Det at Caruso først prøver å gjøre det som er «det riktige», bare for å trekke seg tilbake da det viser seg å være for vanskelig å ofre sitt eget liv for «saken», gjør scenens uttrykk enda sterkere. Dette er kanskje Odin Teatrets mest tydelige bidrag til Fugleelskernes endelige versjon.

Den kanskje største forskjellen mellom 1964- og 1966-teksten er måten sanger brukes på. Skuespillets endelige versjon inneholder til sammen 14 sanger, der en av dem («Dødssangen») blir sunget to ganger i to forskjellige scener (de to «Rettssaksscenene» -4 og 29) ${ }^{16}$. Disse sangene ble - sammen med tilsvarende tekster fra Til lykke med dagen - trykt i diktsamlinger Aske, vind og jord fra 1968, og regnes av mange (f.eks. Wandrup 1984: 132) blant Bjørneboes vakreste lyrikk. I tillegg finner vi mange mindre innslag av musikk, dans og sang i Fugleelskerne fra 1966. I 1964-originalen er det også noen tilsvarende elementer. I scene 3, som blir en slags «introduksjon» til scene 4 (som jeg i doktoravhandlingen min kaller for en «metascene», siden dens handling finner sted utenfor skuespillets egentlige tid og rom) kan man høre «svak marsjmusikk, kanskje Horst Wessel Lied e.l.» (Bjørneboe 1964: 4) ${ }^{17}$. På slutten av den samme scenen (og dessuten på slutten av scene 4) hører man «rungende, øredøvende militærmusikk», nøyaktig slik som i den endelige versjonen. I scene 9 kan vi høre «Fuglevennenes sang», men uten noen nærmere beskrivelse (Ibid.: 12-13). I scene 19, som foregår i lokalene til Albergo Dante $^{18}$, synger alle fugleelskerne en sang: «En vildand svømmer stil-l-le / ve-ed ø-ens brede kyst / osv.» (Ibid.: 20). Sangens tekst er diktet «Snøfuglen», skrevet av Johan Sebastian Welhaven. Koret synger om «vildanden» noen ganger i scene 19, og i tillegg på slutten av scene 21 (Ibid.: 27). I 1966-versjonen blir Welhavens tekst erstattet av Bjørneboes egen «Fugleelskernes sang» (Bjørneboe 2005a: 112-113). En sats av Beethovens 9. symfoni (som brukes i skuespillets finale i den endelige versjonen) blir dessuten spilt på slutten av scene 23 i originalversjonen (Bjørneboe 1964: 34). Dessuten kan vi høre barnekoret som synger den kjente barnesangen «Alle fugler små de er» på slutten av scene 26 (Bjørneboe 1964: 37). Mens Bee-

\footnotetext{
${ }^{16}$ Musikken til sangene i Fugleelskerne ble skrevet av Berliner Ensembles musikalske leder, Hans-Dieter Hosalla.

${ }^{17}$ I 1966-versjonen er det også «marsjmusikk» her (Bjørneboe 2005a: 94), dog uten antydning til hva slags musikk det skal være.

${ }^{18}$ Hotel Dante i den endelige versjonen.
} 
thoven i den endelige versjonen blir erstattet av «Rosa-sangen» (Bjørneboe 2005a: 121), finnes det ingen musikalske innslag på slutten av scene 26 i 1966-versjonen.

De 14 sangtekstene måtte altså ha blitt skrevet mellom 1964 og 1966 - noen av dem allerede før oktober 1965, siden vi finner elementer av to sanger som senere ble brukt i skuespillets ferdige versjon i scenarioet til Odin Teatret ${ }^{19}$. Den ene er den ovennevnte «Dødssangen», som synges to ganger også hos Barba: første gang når faren forteller et eventyr til sin datter (Odin Teatret 1964 [1965?]: upaginert, ark 5), og for andre gang (i et utdrag) i den siste scenen, når datteren henger seg (Ibid.: upaginert, siste ark (9)). En annen sang vi finner (kun i ett lite element) både i Odin Teatrets scenario og i 1966-versjonen - den berømte «Mea maxima culpa». Hos Barba synges den riktignok ikke, men blir en del av en replikk til faren/Wethal:

Et lodd er tilfaldt meg som er liflig, og en arv som behager meg, vær ved godt mot og deres hjerte skal være sterkt, for jeg skal forløse dere fra deres ansvar. - Hvem er et menneske og ikke skyldbevisst, hvem er et menneske som ikke vet at han bør frykte all rettferdighet? (Ibid.)

Så siterer han sangteksten videre i sine fire neste replikker ${ }^{20}$. Det at disse to sangene - som vi finner både i skuespillets endelige tekst $o g$ hos Barba, men $i k k e$ i originalteksten fra 1964 - er et godt bevis på at de to vennene holdt kontakt med hverandre mens de arbeidet med hver sin versjon av stykket, og utvekslet både meninger og materiale.

Men Barba var ikke den eneste Bjørneboe hentet ideer og inspirasjon fra i den siste innspurten til Fugleelskerne. Han holdt tett kontakt med Berliner Ensemble ${ }^{21}$ samt sine danske venner, Jens Kruuse og Ionesco-eksperten Christian Ludvigsen (Rem 2010: 199).

Det faktum at det var til sammen fire Brecht-mennesker involvert i skapelsesprosessen rundt Fugleelskerne er ikke tilfeldig. Stykket ble til i en periode som var preget av Bjørneboes store begeistring for det episke teatret og regnes - ikke uten grunn -

${ }^{19}$ I mars 1965 skrev Bjørneboe til Gordon Hølmebakk, redaktøren sin i Gyldendal: «Stykket er på en måte O.K. som det er, men jeg tror det har helt store muligheter, og at det bør arbeides til det ytterste med det. Det skal avgjort ha sanger, det også, fordi sangene både mildner og skjerper og fordyper stykket. Hvis jeg får arbeidsro, har jeg det snart ferdig. Alle sangtemata er ferdige. (Bjørneboe 2006: 569)», noe som tyder på at arbeidet med sangene begynte «på alvor» først etterpå.

${ }^{20}$ I 1966-versjonen synges «Mea maxima culpa» i scene 29, under «Rettssaken» (Bjørneboe 2005a: 142-143).

${ }^{21}$ Peter Palitzsch, som allerede i 1963 ga sin «velsignelse» til stykket og som skulle være ansvarlig for iscenesettelsen, men som senere kom med innvendinger om at det ble «for metafysisk» og derfor ga regien til sin kollega, Carl Weber. Andre teatermenn fra Bliner Ensemble som bidro til stykkets endelige form, var Manfred Wekwerth samt Hans-Dieter Hosalla. Sistnevnte komponerte musikken til sangtekstene. 
som et av hans «brechtianske» skuespill. Derfor oppfatter jeg endringene som ble innført mellom 1964 og 1966, hovedsakelig som innføring av nye «episke» elementer i skuespillet. Her er det stort sett snakk om tekniske løsninger som har som mål å fremkalle den såkalte Verfremdungseffekten hos tilskueren, altså vekke ham fra teaterillusjonen. V-effekten hos Bjørneboe har et litt annerledes mål enn hos Brecht, men dette spørsmålet skal jeg ikke ta for meg i denne teksten. En nærmere beskrivelse av dette fenomenet gir jeg i doktoravhandlingen min (Drozdowska 2014). Noen av de elementene jeg kaller for «episke», finnes allerede i 1964-versjonen og blir bare forsterket; noen blir innført av Bjørneboe først i den endelige versjonen. Jeg ønsker bare å nevne her at bortsett fra dette (og alt det jeg skriver ovenfor) er forskjellene mellom disse to versjonene veldig små. Man kan for eksempel observere endringer i lengden på scenene: Scene 7, som i 1964-versjonen består av en samtale mellom Caruso, Sandro, Marco, Fidele, Piccolino og Rosa (Bjørneboe 1964: 12), er i den endelige versjonen erstattet av en scene der Frøken Herz synger sangen «Fedrelandssalme» (Bjørneboe 2005a: 104-105). Dessuten er scene 14 betydelig lengre i 1964enn i 1966-versjonen. Ellers er det nesten ingen store forskjeller.

Allerede i 1964-teksten er det flere elementer som bryter med teaterillusjonen og som, gjennom sin groteske virkning, minner tilskuerne om at det de ser på scenen, ikke er «virkelig». Blant disse elementene (som forresten også finnes i den endelige versjonen) kan følgende nevnes: «metascenen» (scene 4), bruk av det grafiske fuglesymbolet (gjennom hele teksten), fremstillingen av Ziegenstein som en mann i kvinneklær (scene 24) samt innslag av absurd humor: som for eksempel radiosendingen om «romskip Iwan III, nu på vei mot planeten Jupit...» (Bjørneboe 1964: 1). Denne sendingen gjentas hele tre ganger i den originale versjonen (scener 1, 9 og 27), mens i den endelige teksten hører vi om romskipet kun én gang (scene 1). I scene 27 kommer Cavalli med en erklæring: «Jeg liker fete kvinner, Sandro» (Ibid.: 38), som virker komisk siden den ikke passer til situasjonen i det hele tatt (mennene venter på de to tyskerne de skal henrette). Replikken med fete kvinner blir brukt flere ganger i den endelige teksten; i scene 1 samt i scene 29, når Caruso skal henge seg (da blir den enda mer upassende). Slike overraskende, og dermed komiske, replikker blir i tillegg forsterket av manipulasjon med pauser og venting i 1966-teksten. Pausene er ofte (som f.eks. i scene 1 og på slutten av scene 29) såpass lange at de blir uutholdelige, og hver replikk som avbryter dem, virker komisk. Mangel på samsvar mellom form og innhold blir ytterligere forsterket i 1966-versjonen. I scene 27 diskuterer Sandro og Cavalli bordeller, vin og mat i forskjellige byer, samtidig som de fikser tauene fugleelskerne skal henges i. De kan ikke bli enige om tauene har riktig lengde (denne delen av samtalen finnes også i originalscenarioet).

I tillegg er det verdt å nevne to elementer som er typiske for episk teater, og som forekommer i den endelige, men ikke i den opprinnelige versjonen. Det første er den såkalte «piskescenen» i scene 4: «Caruso blir under det følgende pisket av 
Johannes. Det er en pantomimisk, abstrakt prosess, hvor Caruso kryper på gulvet og Johannes følger etter ham med pisken. Man hører slagene meget tydelig» (Bjørneboe 2005a: 98). Her er det altså et innslag av pantomime, en plutselig endring av teaterform, noe som må virke veldig fremmedgjørende på tilskuerne ${ }^{22}$. Det andre elementet er henvendelser «ad spectatores», altså «til publikummet», noe som er veldig typisk for Brechts episke teater. Tilskueren blir klar over sin rolle, dermed forsvinner illusjonen. Greifenklau henvender seg til publikummet på denne måten i scene 26 (Ibid.: 126). Når man ser på disse elementene, sammen med de 14 sangene, er det forståelig at Vgs omtale av Fugleelskerne vektla en «mildt sagt overveldende» Brecht-innflytelse (Rem 2010: 244). Vi kan altså avslutte denne analysen med å si at alle endringene i Fugleelskerne, som ble innført mellom 1964 og 1966, i hovedsak hadde som mål å bidra til en fremmedgjørende effekt på publikum.

\section{Avslutning}

I denne teksten har jeg forsøkt å presentere Ornitofilenes/Fugleelskernes historie, fra det originale manuset som Barba mottok fra Bjørneboe, gjennom Odin Tetarets versjon av skuespillet, til Bjørneboes endelige versjon som fikk sin premiere på Nationaltheatret i 1966. Det er åpenbart at de to versjonene som «vokste ut»av 1964-manuset er veldig forskjellige - ikke bare på grunn av rent tekniske aspekter, men også teaterfilosofien som stod bak dem. Mens Barba var sterkt inspirert av Grotowski, er det Brechts teori som er mest synlig i Fugleelskerne fra 1966. Men samtidig forblir disse to versjonene i dialog med hverandre. Og når man undersøker dem i forhold til hverandre, og i forhold til det opprinnelige manuset, ser man en sammenheng som ikke bare gjør en fullstendig historisk analyse av tekstene mulig, men som også bidrar til å gjenskape en fortelling om forskjellige syn på teater og deres tolkning i 1960-tallets Norge.

Å kunne besøke Odin Teatret, bo der i flere dager, snakke med mennesker som var med på å danne norsk - men selvsagt også internasjonal - teaterhistorie; se gjen-

\footnotetext{
${ }^{22}$ Det er mulig at inspirasjonen for denne scenen ble hentet fra forestillingen av Henryk Tomaszewskis pantomime-teater som Bjørneboe så i Oslo i mars 1963 (Bjørneboe 2003b), eller rett fra Ornitofilene der det også finnes en piskescene. Torgeir Wethal, som blir pisket, kryper på gulvet. Den som slår ham (Tor Sannum), er kledd som en bøddel, med høye støvler og en karakteristisk bøddelmaske. Wethal har et rep rundt halsen og bøddelen holder den andre enden av repet. Hos Barba pisker bøddelen seg selv med repet, mens fangen reagerer på slagene (Kvamme 2004: bilde på ikke-nummerert side).
} 
nom arkivene og samarbeide med de dyktige ansatte der, var en meget verdifull opplevelse. Jeg håper at forskningsarbeidet jeg gjorde ved OTA kan bidra til bedre forståelse av prosessene Odin Teatret var med på å skape, og at denne teksten kaster litt lys på den delen av Bjørneboes forfatterskap som var tett knyttet til Eugenio Barbas gruppe. Jeg ønsker med dette å takke de ansatte ved OTA (Francesca Romana Rietti og Sabrina Martello) samt Barba og Laukvik for deres tålmodighet og velvilje, og for at de hjalp meg å finne svar på mine spørsmål.

\section{Kilder}

Primære kilder

Bjørneboe, J. (1964). Fugleelskerne. Scenario av Jens Björneboe. Scenarioets første versjon, tilgjengelig i arkivene til Odin Teatret: OTA (Odin Teatret Archives) - Documents, Fonds Odin Teatret, Series Performances, Sub-Series Perf-B, Perf-B, b. 1.

Bjørneboe, J. (2005a) [1966]. Fugleelskerne. I: J. Bjørneboe. Samlede skuespill. Oslo: Pax forlag A/S.

Litteratur

Bjørneboe, J. (1968). Aske, vind og jord: sanger, viser, og dikt. Oslo: Gyldendal.

Bjørneboe, J. (2003a) [1967]. «Fugleelskerne» og Den Internasjonale Festivalen i Venezia. I: J. Bjørneboe. Norge mitt Norge. Oslo: Pax forlag A/S.

Bjørneboe, J. (2003b) [1967]. Det polske pantomimteateret. Samtale med Henryk Tomaszewski. I: J. Bjørneboe. Om teater. Oslo: Pax forlag AS.

Bjørneboe, J. (2005b [1965]). Til lykke med dagen. I: J. Bjørneboe. Samlede skuespill. Oslo: Pax Forlag A/S, s. 11-71.

Bjørneboe, J. (2006 [1965]). Brev til Gordon Hølmebakk, 05.03.1965. I: J. Bjørneboe. Bjørneboes beste. Gyldendal-årene. Oslo: Gyldendal.

Drozdowska, K. (2014). Jens Bjørneboes episke teater. Doktoravhandling forsvart ved Det filologiske institutt, Universitetet i Gdańsk.

Figueiredo, I. de (2014). Ord/kjøtt. Norsk scenedramatikk 1890-2000. Oslo: Cappelen damm.

Garton, J. (1985). Jens Bjørneboe, Prophet without Honor. London: Greenwood Press.

Kvamme, E. (2004). Kjoere Jens, kjoere Eugenio: om Jens Bjørneboe, Eugenio Barba og opprørernes teater. Oslo: Pax Forlag A/S.

Martin, J. (1996). Keeper of the Protocols. The works of Jens Bjørneboe in the Crosscurrents of Western Literature. New York: Peter Lang Publishing.

Rem, T. (2009). Sin egen herre. Oslo: Cappelen Damm.

Rem, T. (2010). Født til frihet. Oslo: Cappelen Damm.

Turner, J. (2004). Eugenio Barba. London: Routledge.

Wandrup, F. (1984). Jens Bjørneboe: mannen, myten og kunsten. Oslo: Gyldendal.

Wójtowicz, A. (2014). „Barba Eugenio tą razą w rozmowie był bardziej powściągliwy”. Eugenio Barba w raportach Służby Bezpieczeństwa. W: Z. Dwojakowska (red.). Tysiąc i jedna noc. Związki Odin Teatret $z$ Polską. Wrocław: Instytut im. Jerzego Grotowskiego, s. 23-34. 


\section{Arkivressurser}

OTA (Odin Teatret Archives) - Documents, Fonds Eugenio Barba, Series Letters, Barba-Letters, b. 1.

OTA (Odin Teatret Archives) - Documents, Fonds Eugenio Barba, Series Miscellaneous, Barba-Miscellaneous, b. 7.

OTA (Odin Teatret Archives) - Documents, Fonds Odin Teatret, Series Activities, Activities, b. 1 .

OTA (Odin Teatret Archives) - Documents, Fonds Odin Teatret, Series Performances, Sub-Series Perf-B, Perf-B, b. 1.

OTA (Odin Teatret Archives) - Documents, Fonds Wethal, Series Wethal, Wethal, b. 39.

Intervjuer

Intervju med Else Marie Laukvik, Odin Teatret, Holstebro, 1.09.2016.

Intervju med Eugenio Barba, Odin Teatret, Holstebro, 6.09.2016.

Elektroniske og audiovisuelle ressurser

Jens Bjørneboe - Diktere og masochister. (2004). En biografisk serie (i to deler) produsert av NRK og sendt på NRK1 den 13. og 20. desember 2004.

Odin Teatret. (1964 [1965?]). Ornitofilene. Original text of the performance, http://www.odinteatretarchives.com/odinstory/doc-original-text-of-the-performance-1964 (tilgang: 9.01.2017).

Odin Teatret. (1965) Filmklipp av Ornitofilene, https://www.youtube.com/watch?v=WdBOhKu8zvY (tilgang: 4.01.2017).

Odin Teatret. (2008). Ornitofilene. Text of the performance revised by Else Marie Laukvik, http://www.odinteatretarchives.com/odinstory/doc-text-of-the-performance-revised-byelse-marie-laukvik-2008 (tilgang: 9.01.2017). 